\author{
ПЕРЕВІРКА ЕФЕКТИВНОСТІ ПЕДАГОГІЧНИХ УМОВ \\ ГРОМАДЯНСЬКОГО ВИХОВАННЯ УЧНІВ СТАРШИХ КЛАСІВ \\ НА ОСНОВІ НАЦІОНАЛЬНИХ ТРАДИЦІЙ

\section{CHECKING THE EFFECTIVENESS OF PEDAGOGICAL CONDITIONS OF CIVIC EDUCATION OF SENIOR STUDENTS ON THE BASIS OF NATIONAL TRADITIONS}

Стаття присвячена перевірці ефрективності педагогічних умов громадянського виховання учнів старших класів на основі національних традицій. Автором обгрунтовано такі методи дослідження, як вивчення икільної документації, педагогічне спостереження, опитування (бесіда, анкетування, узагальнення незалежних характеристик), порівняння, оцінювання (експертна оцінка, самооцінка), створення виховуючих ситуачій, педагогічний експеримент (констатувальний та формувальний), а також різноманітні діагностичні методики, які дозволяли виявити результативність застосування розроблених педагогічних умов, коректувати методику їх подальшої реалізації.

Звертається увага на порівняння результатів у контрольній й експериментальній групах окремо за кожним критерієм, а також за їх сукупністю. Проводились узагальнення, систематизація $i$ теоретичний аналіз отриманих результатів дослідно-експериментальної роботи, зіставлення їх із результатами констатувального етапу експерименту. Формувальний етап педагогічного експерименту передбачав послідовне здійснення педагогічних заходів, спрямованих на громадянське виховання учнів старших класів на основі національних традицій.

Аналіз результатів експериментального дослідження свідчить про ефективність розроблених і впроваджених в освітній прочес загальноосвітнього навчального закладу педагогічних умов громадянського виховання учнів старших класів на основі національних традицій. Автор доходить висновку, що громадянська вихованість учнів в експериментальній групі зумовлена:

доповненням змісту навчальних предметів питаннями громадянського виховання учнів та введення спецкурсу «Громадянське виховання учнів в загальноосвітній школі»; використанням виховного потенціалу позааудиторних заходів для розвитку мотивації учнів до самовдосконалення;

поєднанням традииійних та інноваційних форм, методів та засобів громадянського виховання учнів старших класів забезпеченням методичного супроводу навчальних та виховних заходів; підвищенням громадянської к культури педагогічних працівників загальноосвітніх навчальних закладів,

Запропоновані педагогічні умови громадянського виховання учнів старших класів на основі національних традицій $\epsilon$ ефрективними i дозволяють оптимізувати зазначений процес.

Ключові слова: експериментальне дослідження, фрормувальний етап експерименту, учні старших класів, загальноосвітній навчальний заклад, громадянська вихованість, національні традиції.

The article is devoted tochecking the effectiveness of pedagogical conditions of civic education of senior students on the basis of national traditions. The author substantiates such research methods as studying school documentation, pedagogical observation, survey (conversation, questionnaire, generalization of independent characteristics), comparison, evaluation (expert assessment, self-assessment), creation of educational situations, pedagogical experiment (ascertaining and formative), and various diagnostic methods that allowed to identify the effectiveness of the developed pedagogical conditions, to adjust the method of their further implementation.

Attention is paid to the comparison of results in the control and experimental groups separately for each criterion, as well as for their totality. Generalization, systematization and theoretical analysis of the obtained results of experimental work were carried out, their comparison with the results of the ascertaining stage of the experiment. The formative stage of the pedagogical experiment provided for the consistent implementation of pedagogical activities aimed at civic education of high school students on the basis of national traditions.

The analysis of the results of the experimental research testifies to the effectiveness of the pedagogical conditions of civic education of high school students developed and implemented in the educational process of the general educational institution on the basis of national traditions. The author concludes that the civic education of students in the experimental group is due to:

supplementing the content of subjects with issues of civic education of students and the introduction of a special course «Civic education of students in secondary school»;

using the educational potential of extracurricular activities to develop students' motivation for selfimprovement;

a combination of traditional and innovative forms, methods and means of civic education of high school students;

providing methodological support for educational activities;

raising the civic culture of pedagogical staff of secondary schools.

The proposed pedagogical conditions of civic education of high school students on the basis of national traditions are effective and allow to optimize this process.

Key words: experimental research, formative stage of the experiment, high school students, secondary school, civic education, national traditions. 
Постановка проблеми в загальному вигляді. У процесі теоретичного аналізу досліджень та проведеного нами констатувального етапу експерименту було виявлено, що традиційно організований процес виховання учнів старших класів загальноосвітніх навчальних закладів не забезпечує повною мірою можливості для громадянського виховання на основі національних традицій.

Експериментальна перевірка ефрективності педагогічних умов громадянського виховання учнів старших класів на основі національних традицій передбачала розробку методики дослідження. Проведення експерименту передбачало поєднання структурних елементів методики, визначення етапів та порядку проведення дослідної роботи, вивчення та інтерпретації його результатів. Актуальність проведеного дослідження полягає в тому, що під час експерименту здійснювався цілеспрямований та керований вплив на процес громадянського виховання учнів старших класів. Педагогічний експеримент проводився в умовах освітнього середовища загальноосвітнього навчального закладу, його результати мають значимість для теорії і практики виховання.

Аналіз останніх досліджень і публікацій. Результати дослідження педагогічних умов громадянського виховання учнів знайшли своє відображення в працях А. Бекірової [1], Л. Корінної [2], К. Пекач [3], О. Федоренко [4] та ін. Проведене нами дослідження підтверджує сорормульовані ними положення. Зокрема, ми погоджуємося 3 визначенням таких «педагогічних умов виховання громадянської відповідальності учнів у системі виховної роботи ліцеїв: фрормування готовності учителів і класних керівників до виховання громадянської відповідальності учнів; забезпечення кооперації зусиль педагогів, батьків, громадських організацій щодо виховання і самовиховання громадянської відповідальності учнів; розвиток дієвих органів учнівського самоврядування та залучення до участі в них вихованців; включення до змісту програм навчальних предметів тем та питань щодо громадянського виховання учнів ліцеїв» [3, с. 7].

Нам імпонує підхід, за яким «педагогічними умовами формування основ громадянської культури молодших школярів у позаурочній діяльності $€$ такі: особистісно орієнтований підхід до виховання; врахування психологічних особливостей розвитку дітей молодшого шкільного віку; забезпечення можливостей прояву усвідомлених знань і набутих якостей у поведінці; підвищення професійної компетентності вчителів початкових класів із формування основ громадянської культури молодших школярів у позаурочній діяльності» [1, с. 8].

Значний інтерес для нашого дослідження становить підхід О. Федоренко, зокрема запропоновані дослідницею педагогічні умови фрормування національно-патріотичної вихованості в учнів основної школи: упровадження методики фрормування національно-патріотичної вихованості учнів основної школи; внесення ціннісних складників у зміст навчальних предметів; розгортання культурно-освітнього простору для активно творчої національно-патріотичної діяльності учнів; здійснення соціально значущих національно-патріотичних справ та вчинків [4, с. 20]. Їх ефективність авторкою підтверджена шляхом фрормувального експерименту.

Виділення не вирішених раніше частин загальної проблеми. Наукові положення, висновки та рекомендації, які містяться в зазначених вище та інших наукових дослідженнях, мають велику цінність для вирішення проблеми громадянського виховання учнів старших класів. Однак у більшості цих праць не брались до уваги особливості реалізації їх саме на основі національних традицій. Тому нами зроблена спроба акцентувати на цьому аспекті.

Мета статті. Метою статті $€$ перевірка ефрективності педагогічних умов громадянського виховання учнів старших класів на основі національних традицій.

Виклад основного матеріалу. Відомо, що комплексному та ефрективному вивченню педагогічних явищ сприяє використання такого методу дослідження, як педагогічний експеримент. Він застосовується з метою об'єктивної перевірки правильності гіпотези дослідження. Методика проведення педагогічного експерименту становить інтерес у вітчизняній [3-5] та зарубіжній науковій літературі [6].

Для нашого дослідження цей метод є цікавим, оскільки дає змогу здійснювати активний керований вплив на процес громадянського виховання учнів старших класів. Метод експерименту в нашому дослідженні пов'язаний із реалізацією та перевіркою ефективності педагогічних умов громадянського виховання учнів старших класів, активним втручанням у педагогічну ситуацію з боку дослідника і передбачає цілеспрямоване спостереження.

Експериментальна робота охоплювала констатувальний та фрормувальний етапи. Як гіпотезу педагогічного експерименту було висунуто припущення про те, що ефективність громадянського виховання учнів старших класів на основі національних традицій зросте, якщо воно буде реалізовуватись у відповідних педагогічних умовах.

У процесі вирішення експериментальних завдань нами застосовано такі методи дослідження: вивчення шкільної документації, педагогічне спостереження, опитування (бесіда, анкетування, узагальнення незалежних характеристик), порівняння, оцінювання (експертна оцінка, самооцінка), створення виховуючих ситуацій, педагогічний експеримент (констатувальний та фрормувальний). 
Метод дослідження - це певний спосіб і прийом вирішення наукової проблеми. Щоб виключити багатогранність поняття «метод дослідження», ми використовуємо поняття «техніка дослідження». Під технікою дослідження В. Райко розуміє практичні дії, регульовані ретельно розробленими вказівками, що дозволяють отримувати оптимальні, вірогідні фракти та відомості. Вони, як правило, мають характер інструкцій або алгоритмів, що стосуються збирання емпіричного матеріалу [5]. У системі методів педагогічного дослідження розрізняються загальнонаукові (емпіричні та теоретичні) і спеціальні (конкретно-наукові) методи. Від вибору та вдалого поєднання методів залежить результативність наукового дослідження.

Емпіричні методи (різні види спостережень, опитувань, вивчення документів тощо) використовувались на початковому етапі дослідження процесу громадянського виховання учнів старших класів на основі національних традицій. За допомогою цих методів здійснювався пошук фрактичного матеріалу.

Метод спостереження як один з основних емпіричних методів педагогічного дослідження полягає в безпосередньому сприйнятті педагогічних явищ із метою вивчення їх специфічних змін у конкретних умовах, а також у пошуку змісту цих явищ. За допомогою цього методу вивчалися зовнішні вияви громадянської вихованості учнів старших класів у різних умовах.

Узагальнення $\epsilon$ самостійним методом, але часто використовувалось нами спільно з іншими методами (під час бесіди, під час індивідуального дослідження). Метод опитування базується на цілеспрямованому отриманні інорормації шляхом усних або письмових запитань і реалізується у трьох фрормах: бесіда, інтерв'ю, анкетування. Бесіда $є$ методом отримання інорормації на основі словесного спілкування. Цей метод застосовувався як допоміжний метод педагогічного дослідження для уточнення висновків, отриманих іншими методами. У низці випадків він може застосовуватися для отримання первинної інфрормації.

Інтерв'ю $є$ методом збору первинної інорормації в педагогічних дослідженнях. На відміну від бесіди, ролі учасників інтерв'ю закріплені, нормовані, а цілі задані завданнями нашого дослідження.

Анкетування $є$ методом педагогічного дослідження за допомогою анкет. Анкетування, на відміну від інтерв'ю, здійснювалося заочно. Зміст запитань і спосіб відповідей на них заздалегідь планувався. Анкетний метод $€$ порівняно економним методом, який дає змогу аналізувати й обробляти дані за допомогою статистики. Цей метод застосовувався в комбінаціях з іншими методами. Під час бесід за спеціально розробленими анкетами з'ясовувались зміни у ставленні учнів до громадянського виховання, уточнювався рівень їхньої громадянської вихованості. Дослідники [5; 10] вважають анкетування результативним методом дослідно-експериментальної роботи, оскільки він $€$ різновидом письмового опитування та методом масового збирання матеріалу. Також під час вибору цього методу ми керувалися тією обставиною, що за умови правильної організації анкетування унеможливлюється вплив респондентів один на одного. Цей метод застосовувався в комбінаціях з іншими методами.

Важливим моментом дослідження було педагогічне прогнозування. Як вид наукового прогнозування воно являє собою спеціально організований комплекс наукових досліджень, спрямованих на одержання достовірної випереджальної інфрормації про розвиток відповідних педагогічних об'єктів із метою оптимізації змісту, методів, засобів та організаційних форм навчально-виховної діяльності [7, с. 115].

На певному етапі дослідження емпіричні методи не забезпечують у повному обсязі вирішення поставлених завдань. Тоді виникає необхідність використання теоретичних методів дослідження, за допомогою яких здійснюється переробка отриманих емпіричних даних.

Кількісна та якісна обробка й інтерпретація зібраної і систематизованої інфрормації проводились за допомогою методів математичної статистики.

Запроваджувалися різноманітні діагностичні методики, які дозволяли виявити результативність застосування розроблених педагогічних умов, коректувати методику їх подальшої реалізації. Зверталася увага на порівняння результатів у контрольній й експериментальній групах окремо за кожним критерієм, а також за їх сукупністю. Авторами проводилось узагальнення, систематизація і теоретичний аналіз отриманих результатів дослідно-експериментальної роботи, зіставлення їх із результатами констатувального етапу експерименту. На кожному етапі експериментального дослідження ставилися конкретні завдання. Для перевірки ефрективності в основному використовувалися ті ж методи, що на попередньому (констатувальному) етапі. Відбувалося спостереження та експертна оцінка з боку спеціально підібраної групи експертів (16 осіб). До складу цієї групи увійшли досвідчені представники від колективу педагогічних працівників.

Метод експертних оцінок $є$ важливим методом дослідження, який ґрунтується на припущенні, що кожен інтегральний об'єкт можна подати як комплексний кількісний показник, тобто як суму добутків складників об'єкта та відповідних йому коефіцієнтів вагомості [8, с. 151]. Коефіцієнти вагомості відображають вплив кожної складової частини об'єкта на комплексний кількісний показник. При цьому загальна сума коефіцієнтів, за правилом 
нормування, дорівнює одиниці. Кількісне значення коефіцієнтів вагомості визначали експерти. Тому, якщо інтегральним об'єктом $€$ рівень громадянської вихованості учнів, його можна визначити як комплексний кількісний показник:

$$
\mathrm{K}_{\text {eф }}=\mathrm{K}_{\mathrm{B} 1} \cdot \mathrm{K}_{\mathrm{iK}}+\mathrm{K}_{\mathrm{B} 2} \cdot \mathrm{K}_{\mathrm{MT}}+\mathrm{K}_{\mathrm{B} 3} \cdot \mathrm{K}_{\text {да }} \text {, }
$$

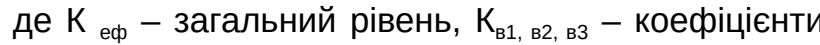
вагомості кожного критерію. При цьому

$$
\mathrm{K}_{\mathrm{B} 1}+\mathrm{K}_{\mathrm{B} 2}+\mathrm{K}_{\mathrm{B} 3}=1 .
$$

У результаті проведеного анкетування серед 12 експертів, які оцінювали кожного учня експериментальної та контрольної груп за кожним показником із трьох критеріїв (інформаційно-пізнавальним, ціннісно-мотиваційним, діяльніснорефлексивним), виявлено однакові значення коефріцієнтів вагомості оцінки рівня громадянської вихованості учня. Їх значення прийнято:

$$
\mathrm{K}_{\mathrm{B} 1}=\mathrm{K}_{\mathrm{B} 2}=\mathrm{K}_{\mathrm{B} 3}=0,33 .
$$

На основі зазначених критеріїв та показників було визначено три рівні громадянської вихованості старшокласників на основі національних традицій.

Отже, визначені критерії та показники свідчать про те, що кожен із визначених критеріїв громадянської вихованості учнів є об'єктом, який діагностується та лише умовно виділений у цілісному процесі громадянського виховання. У сукупності критерії та їх показники характеризують громадянську вихованість учнів як результат громадянського виховання - процесу, що можна і необхідно цілеспрямовано організовувати, управляти та при цьому прагнути досягнення певних результатів.

Порівняння результатів формувального етапу експерименту в контрольній й експериментальній групах виконувалось окремо за кожним із критеріїв, а також за інтегральним показником ефрективності $\mathrm{K}_{\text {eф }}$, середнім зваженим на сукупності цих критеріїв.

Діагностування громадянської вихованості здійснювалось шляхом вивчення істотних ознак громадянської вихованості, їх фрорм вираження як реалізованих цілей громадянського виховання. Як стверджують науковці, «особливістю діагностики $€$ прогностичний характер ії висновків. Прогноз потрібний для того, щоб внести необхідні корекції вихованості учня: підсилити бажані і нейтралізувати небажані тенденції». У цьому розумінні діагностування здійснюється не лише з метою внесення у подальшому коректив у виховний процес, але й з метою реалізації індивідуального підходу до учнів. Проте, оскільки розрив між метою та досягнутими результатами спостерігається постійно, завдання діагностики громадянської вихованості актуальне для всіх військовослужбовців, ступінь громадянської вихованості навчального колективу визначається на підставі своєрідного поєднання громадянської вихованості всіх його представників [9].

Для підтвердження дієвості педагогічних умов громадянського виховання учнів старших класів на основі національних традицій у 2018-2019 та 2019-2020 навчальних роках нами було організовано та проведено формувальний етап експерименту. У ньому брали участь 486 учнів . 3 них до контрольної групи (далі - КГ) увійшли 242, до експериментальної (далі - ЕГ) - 244 учня. У формувальному етапі експерименту брали участь 12 осіб педагогічних працівників.

Формувальний етап педагогічного експерименту передбачав послідовне здійснення педагогічних заходів, спрямованих на громадянське виховання учнів старших класів на основі національних традицій.

Критерії вихованості - це ознаки, на основі яких можна робити висновок про рівні вихованості учнів, оцінити результати виховного впливу різноманітних засобів. ОТже, критерії громадянської вихованості - це теоретично розроблені показники рівня сорормованості громадянських якостей учня. У педагогічних дослідженнях [9-10] науково обґрунтовані критерії визначаються «мірилом», «еталоном» оцінювання досліджуваного явища, дають змогу провести педагогічну діагностику, визначити рівні сорормованості та простежити динаміку його розвитку, зосередити увагу на окремих недоліках та окреслити напрями педагогічної роботи. Звідси випливає, що ставлення особистості до дійсності, самого себе, рідного краю, суспільства $€$ мірилом його громадянської вихованості.

Для виявлення загального стану громадянської вихованості учнів старших класів було з'ясовано кількість тих, які відповідають рівням громадянської вихованості в експериментальній та контрольній групах до початку фрормувального етапу експерименту, та порівняно їх результати.

3 метою визначення кількісних оцінок громадянської вихованості, з огляду на результати експертної оцінки, була запропонована єдина шкала оцінок громадянської вихованості учнів старших класів:

- високий рівень - більше 80\% правильних відповідей;

- середній рівень - від 41\% до 80\% правильних відповідей;

- низький рівень - менше 40\% правильних відповідей.

Дані щодо складу експериментальної і контрольної груп на початку експерименту свідчать, що показники експериментальної і контрольної груп на початковому етапі експерименту майже однорідні. Це уможливлює забезпечення необхідної чистоти дослідження. 
На заключному етапі педагогічного експерименту здійснювалося опрацювання отриманих результатів. Проводилось їх узагальнення, систематизація і теоретичний аналіз, зіставлення 3 результатами, отриманими за допомогою інших емпіричних та теоретичних методів дослідження. На заключному етапі експерименту відбувався опис одержаних результатів та впровадження педагогічних умов громадянського виховання учнів старших класів на основі національних традицій в освітній процес загальноосвітнього навчального закладу.

Результати фрормувального етапу експерименту свідчать, що в експериментальній групі відбулися більш значимі зміни за вибраними критеріями та показниками. Так, кількість учнів із високим рівнем громадянської вихованості в експериментальній групі становила 29,2\% проти $18,7 \%$, у контрольній - 20,9\% проти 19,5\%. Кількість учнів із низьким рівнем в експериментальній групі зменшилась від 21,6\% до 5,8\%, у контрольній - від 22,4\% до 19,3\%. Це підтверджує еорективність визначених педагогічних умов громадянського виховання учнів загальноосвітніх навчальних закладів на основі національних традицій.

Отже, результати експерименту, зокрема аналіз ефективності застосування визначених педагогічних умов громадянського виховання учнів старших класів на основі національних традицій в освітньому процесі загальноосвітнього навчального закладу дають змогу зробити такі висновки: загалом відбулися якісні зміни в експериментальній (суттєві) і контрольній (незначні) групах. Громадянська вихованість учнів в експериментальній групі зумовлена: доповненням змісту навчальних предметів питаннями громадянського виховання учнів та введенням спецкурсу «Громадянське виховання учнів в загальноосвітній школі»; використанням виховного потенціалу позааудиторних заходів для розвитку мотивації учнів до самовдосконалення; поєднанням традиційних та інноваційних фрорм, методів та засобів громадянського виховання учнів старших класів; забезпеченням методичного супроводу навчальних та виховних заходів; підвищенням громадянської культури педагогічних працівників загальноосвітніх навчальних закладів.

Висновки. Отже, завдяки використанню комплексу методів дослідження було здійснено перевірку ефективності педагогічних умов громадянського виховання учнів старших класів на основі національних традицій. Аналіз результатів експе- риментального дослідження свідчить про дієвість розроблених і впроваджених в освітній процес загальноосвітнього навчального закладу педагогічних умов громадянського виховання учнів на основі національних традицій. Перспективу подальших наукових розробок з окресленої проблеми становить визначення, підбір та детальний опис методів громадянського виховання учнів 3 урахуванням вікових, гендерних аспектів, регіональних особливостей фрормування традицій.

\section{БІБЛІОГРАФІЧНИЙ СПИСОК:}

1. Бекірова А. Формування основ громадянської культури молодших школярів у позаурочній діяльності загальноосвітніх шкіл Автономної Республіки Крим : автореср. дис. ... канд. пед. наук : 3.00.07. Київ. 2010. 21 c.

2. Корінна Л.В. Формування громадянських цінностей старшокласників у загальноосвітніх навчальних закладах : автореф. дис. ... канд. пед. наук : 13.00.07. Київ. 2005. 20 с.

3. Пекач К.А. Виховання громадянської відповідальності учнів у системі виховної роботи ліцею : дис. ... канд. пед. наук : 13.00.07. Київ, 2017.

4. Федоренко О.М. Педагогічні умови фрормування національно-патріотичної вихованості в учнів основної школи загальноосвітніх навчальних закладів : автореср. дис. ... канд. пед. наук : 13.00.04. Київ, 2021. 26 c.

5. Райко В.В. Теоретичні і методичні засади фрормування правової культури офріцерського складу Державної прикордонної служби України : монографрія. Хмельницький, 2008. 342 с.

6. Baer L., Campbel J. From Metrics to Analytics, Reporting to Action: Analytics' Role in Changing the Learning Environment. Education and Information Technologies. Boulder, CO: EDUCAUSE, 2012. P. 63.

7. Вихрущ В.О. Методика педагогіки. Навчальний посібник. Тернопіль. 2011. 346 с.

8. Сердюк С. І. Формування професійної надійності майбутніх офріцерів-прикордонників у процесі фрахової підготовки : дис. ... канд. пед. наук : 13.00.04. Хмельницький, 2018. 289 с.

9. Valentina Miroshnichenko, Ihor Bloshchynskyi, Yurii Kuz, Oleh Stavytskyi, Kostiantyn Prontenko, Olha Mysechko, Tetiana Shcheholeva, Tetiana Vakoliuk (2019). Verificación de la eficiencia de las condiciones pedagógicas de la educación militarpatriótica de los futuros oficiales de la guardia fronteriza. Revista Dilemas Contemporáneos: Educación, Política y Valores Año: VII Número: Edición Especial Artículo no: 17 Período: Septembre.

10. Шестопалюк О.В. Громадянське виховання майбутніх учителів: теоретичні і методичні елементи : монографрія. Вінниця : Видавництво «Консоль», 2008. 260 c. 